\title{
Local and Personal Networks in Employment and the Development of Labor Markets: Evidence from the Cut Flower Industry in Ethiopia
}

By

Yukichi Mano

Takashi Yamano

Aya Suzuki

Tomoya Matsumoto

Nov 2010

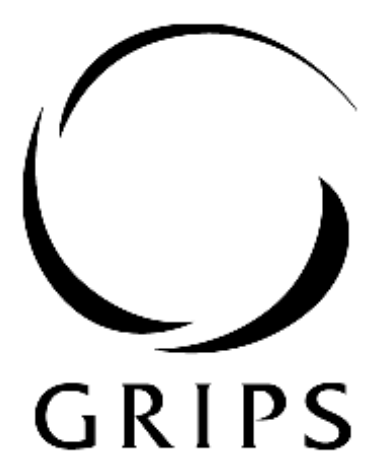

National Graduate institute FOR POLICY STUDIES

National Graduate Institute for Policy Studies 7-22-1 Roppongi, Minato-ku, Tokyo, Japan 106-8677 


\title{
Local and Personal Networks in Employment and the Development of Labor Markets: Evidence from the Cut Flower Industry in Ethiopia
}

\author{
Yukichi Mano $^{\mathrm{AB}}$, Takashi Yamano ${ }^{\mathrm{AB}}$, Aya Suzuki ${ }^{\mathrm{AB}}$, and Tomoya Matsumoto ${ }^{\mathrm{B}}$ \\ ${ }^{\text {A }}$ Foundation for Advanced Studies on International Development \\ ${ }^{B}$ National Graduate Institute for Policy Studies
}

November, 2010

\begin{abstract}
We examine the roles of local and personal networks in the employment process and the emergence and development of the labor market in Ethiopia's growing cut flower industry. Using primary survey data of 320 workers randomly sampled from all 64 farms, we find that workers who were recruited informally using the social ties were paid less than the formally-recruited workers at hiring. However, these workers quickly increased their productivity, and the effect of social ties on wages disappeared over time. Further, we find that the development of labor market for this newly-emerged industry took place particularly within the industrial clusters (100 words).
\end{abstract}

Key Words: Labor, Market, Cluster, Cut Flower, Ethiopia, Africa

JEL Codes: O15, Q12, J33

Contact(for all the authors):

National Graduate Institute for Policy Studies

7-22-1, Roppongi, Minato-ku, Tokyo 106-8677, JAPAN

Email: ayaszk@grips.ac.jp (Aya Suzuki) 


\section{INTRODUCTION}

In developing economies, the creation of non-farm employment opportunities is recognized as an essential pathway out of poverty (Otsuka et al., 2009). However, it is often the case that labor markets in such economies are yet to be well established, and the dissemination of information on such employment opportunities tends to be limited within a local community or personal network. In consequence, the newly established non-farm sector would sooner or later face a labor shortage, and its long-run development and contribution to poverty alleviation could be severely hampered. Thus, the establishment of a well functioning labor market is important to help the non-farm sector develop and play its expected role in poverty reduction.

The existing literature suggests that information on employment opportunities tends to be transmitted through local and personal networks in developing economies to supplement their underdeveloped labor market (e.g., Ben-Porath, 1980). Studies on rural-urban migration in developing economies emphasize the importance of personal networks for new migrants to find jobs in urban areas (Banerjee, 1984; Carrington, 1996). For instance, established migrants tend to help new migrants who come from their home communities or belong to the same ethnic group (Munshi, 2003; Luke and Munshi, 2006). Yamauchi and Tanabe (2008) find that in Indonesia, migrants have a high probability of finding jobs if the proportion of early migrants from the same district is high. Using data from both residents and emigrants from a village in the Philippines, Kajisa (2007) also shows that personal networks help workers obtain non-farm jobs in rural areas. In our view, however, studies on employment process in developing economies are still scarce 
(e.g., Frijiters, 1999; Collier and Garg, 1999), and more importantly, the development process of labor markets beyond the reliance on these personal networks has not been sufficiently examined since its importance was first raised by Marshall (1920).

In order to fill this gap, this paper carefully studies the evolution of the employment channels and the development of the labor market in the young and exponentially growing cut flower industry in Ethiopia. The cut flower industry in Ethiopia is a fast growing industry, having increased its total value of export from USD 2 million in 2004 to USD 104 million in 2008, almost equivalent to 20 percent of the export value of coffee from this country (Table 1). In fact, Ethiopia has become the third largest cut flower exporter in Africa, following Kenya and Zimbabwe. We have detailed primary information on all the 64 farms in the cut flower industry as of 2007, and also on 320 workers randomly sampled from its 21,786 employees. We observe that the flower farms initially employed local villagers who reside in their neighborhood, and gradually started hiring distant farmers who were relatives and friends of their employees. The employment of workers outside these social networks used to be a minor option, but its share has been steadily increasing over time, especially within the industrial clusters ${ }^{1}$ and reached 15 percent of the newly employed as of 2007. These employees outside these social networks earned significantly higher initial wages compared to the workers hired through the social networks. However, the wage rate of the workers hired through the local and personal networks increased at faster rates than the workers outside the networks, and the wage gap soon disappeared. This suggests that those hired through social networks also quickly learn new skills, indicating that this industry not only created employment opportunities for the poor farmers 
but also improved their human capital.

The rest of this paper is organized as follows. Section 2 reviews the literature on the role of personal networks on employment and postulates our main hypotheses, while we describe the cut flower industry in Ethiopia in Section 3. Section 4 describes our dataset, and discusses the descriptive statistics. Our estimation strategy is presented in Section 5. The estimation results are reported and examined in Section 6, and Section 7 concludes this paper.

\section{HYPOTHESES}

At the early stage of an infant industry, the associated input and output markets tend to be underdeveloped, especially in developing economies (Sonobe and Otsuka, 2006). It is widely recognized that personal networks play important roles in economic transactions. ${ }^{2}$ A number of studies have examined the roles of local and personal networks on the employment process. One common hypothesis, the so-called "screening hypothesis" argues that the use of personal networks reduces the cost arising from hidden information about the workers’ quality (Saloner, 1985; Montgomery, 1991; Simon and Warner, 1992). This hypothesis primarily considers occupations requiring high skills and predicts that workers with referrals tend to receive higher initial wage than non-referred workers because the employers have more accurate information about the former. However, because the firms acquire more information about the non-referred over time, this information advantage becomes less important, and thus the growth rate of wages for the referred workers tends to be slow. 
Another strand of the literature considers the cost arising from the hidden action by the worker, the so-called "peer-pressure hypothesis" (Milgrom and Roberts, 1992; Putnam, 2000). This hypothesis considers situations in which the effort levels of the workers are unobservable to the employers. It argues that personal networks act to lower the monitoring cost of referred workers because such workers feel obliged to exert high-level efforts to prevent the introducers from losing face. Because of the peer pressure, employers can afford to pay lower wages to the referred workers than to the non-referred workers to extract the same effort level throughout their careers.

A third hypothesis, which we may refer to as the "information-cost hypothesis," focuses on the role of personal networks on reducing search costs and disseminating information on employment opportunities (Granovetter 1974; Holzer, 1988; Mortensen and Vishwanath, 1994). Observing that the use of informal hiring methods are more widespread in developing countries (Ben-Porath, 1980), particularly in sectors in which fewer cognitive and social skills are required (Holzer 1996), this hypothesis argues that since the referred applicants are typically those who are unable to find jobs elsewhere, their reservation wages are low. Thus, this hypothesis predicts low initial wages for such referred workers (Pistaferri, 1999; Antoninis, 2006).

While these hypotheses have been discussed especially in the labor economics literature, empirical studies, particularly in the context of the non-agricultural labor market in developing economies, are lacking. Considering the importance of informal recruitment channels in developing countries and the significance of the non-agricultural labor market for poverty reduction, it is important to understand the formulation of labor 
markets for a newly emerged industry in a developing country. In our target industry, as we later explain, the tasks required for the workers are quite simple as opposed to the situations considered in the screening hypothesis and workers are constantly and closely monitored by supervisors, which is different from the situations considered in the peer-pressure hypothesis. Thus, problems arising from hidden information or actions may not be important issues. This leads us to conjecture that the information-cost hypothesis best explains the situation in Ethiopia.

We can test which hypothesis holds for the cut flower industry in Ethiopia by exploiting the different predictions derived from these hypotheses. If the initial wages of the workers with informal networks are significantly lower than the initial wages of the formally-recruited workers, the screening hypothesis is rejected. Moreover, if the wage growth rate for the workers with informal networks changes over time in relation to the formally-recruited workers, we can reject the peer-pressure hypothesis.

We expect that the workers formally selected from a large pool of labor force are associated with higher productivity than the workers hired through local and personal networks and should be paid more highly accordingly. Thus, we postulate the following hypothesis:

Hypothesis 1: The workers recruited formally in the labor market tend to be more productive, and, thus, receive higher wages than the workers hired through local and personal networks. 
Secondly, we expect that the labor supply outside the clusters is relatively scarce. Thus, the farms located outside the clusters might pay higher wages, which we may call a “premium," to attract and secure employees with a given level of productivity and to save on searching for substitute workers. Marshall (1920) stressed three major advantages of industrial clusters: (1) information spillovers, (2) the specialization and division of labor among enterprises, and (3) the development of skilled labor markets. This third advantage, i.e., labor market development, seems to be particularly relevant to our focus on the development of the employment process in an industry. It essentially claims that frequent interactions and enhanced information flow among firms and workers in industrial clusters tend to alleviate search frictions typically associated with job-applicants' access to information about the availability of jobs (Stigler, 1961, 1962; Pissarides, 2001), and help job-applicants best match firms, which are trying to fill their vacancies. Furthermore, recent empirical studies on the formation and development of industrial clusters find that the development of skilled labor markets in industrial clusters enhances knowledge diffusion and skill transformation through spin-offs and active labor turnover (Sonobe and Otsuka, 2006). In our understanding, there is no study directly comparing the development of the labor market associated with a particular industry within and outside industrial clusters. Firms located outside industrial clusters may initially enjoy their monopsonic or oligopsonic positions in the local labor market, but they are likely to face difficulty in attracting workers beyond a certain level as potential workers expect to more likely find better jobs in industrial clusters due to the reasons discussed above. As a consequence, firms outside industrial clusters may want to offer wages in excess of 
market-clearing to reduce labor turnover (e.g. Salop 1979; Schlicht 1978; Stiglitz 1987), as replacing workers, which includes the costs of search, recruitment, and training, is costly. The cut flower industry in Ethiopia provides us with such an opportunity to investigate the development and performance of labor market within and outside an industrial cluster.

Hypothesis 2: The farms located outside the industrial clusters face a relative scarcity of labor force due to the underdevelopment of the labor market, and thus they pay higher wages to a worker with a given level of productivity.

We will test these hypotheses on the cut flower industry in Ethiopia. The next section describes this industry in detail.

\section{THE CUT FLOWER INDUSTRY IN ETHIOPIA}

(a) Rapid growth in the cut flower industry

Ethiopia is a country of agriculture, which accounts for more than 50 percent of its GDP, and about 80 percent of the population lives in rural areas as subsistence farmers (The Embassy of Japan in Ethiopia 2008). Her economy has so far depended on coffee for nearly $50 \%$ of the total exports (Table 1). State farms started to export cut flowers to Europe in 1980 (The Embassy of Japan in Ethiopia 2008), but the rapid development of this sector is originally due to the attempts by several private cut flower farms which began operation in the early 1990s (Gebreeyesus and Iizuka, 2010). These farms included both foreign and domestic farms. The high turn-over rates of workers among these farms 
contributed to the development of a pool of skilled labors, who work as supervisors and managers, and further expanded this industry. Following the initial successes, the government realized the importance of this sector and began providing sector-specific supports from the end of 2002. Thereafter, the sector has expanded rapidly as seen in the annual growth rate of this sector of 444\% in 2008 (NBE report cited in Gebreeyesus and Iizuka, 2010).

Table 1 presents the cut flower export value (in Million USD) of selected African countries. Kenya is the largest cut flower exporter in Africa, and it is indeed the third largest cut flower exporter in the world, after Colombia and Ecuador. Kenya's export value increased from USD 91 million in 2000 to USD 446 million in 2008. Ethiopia's cut flower export was negligible until 2003, but it has drastically increased since 2004 from an export value of USD 2 million to USD 104 million in 2008. Although its export value is still only about one quarter of that of Kenya, Ethiopia has become the third largest cut flower exporter in Africa. How did the young Ethiopian cut flower industry achieve such rapid growth in such a short term?

The existing reports point out that Ethiopia has an agro-climatic condition that is well-suited for flower cultivation (Gebreeyesus and Iizuka, 2010). Ethiopia has wide underdeveloped highlands around its capital city Addis Ababa, a climate of high daily temperature and cool nights, sufficient sunlight and rainfall, and vast forests, which are all favorable for flower production. In addition, Ethiopia has an abundant labor supply with a low wage rate, compared to other African countries.

The strong initiative of the Ethiopian government has also contributed to the 
development of the cut flower industry. The government exempted taxes for inputs, revised the investment law for foreign investors, leased land with basic utilities at low prices, and provided special loans through the Development Bank of Ethiopia. As a result, the investment climate in Ethiopia has drastically improved over the past few years, which has led to a huge capital inflow into the Ethiopian cut flower industry.

Another factor is the shift of production sites from Kenya caused by the water pollution in Naivasha Lake in Kenya and the expiration of the ACP/EU Cotonou Partnership Agreement in 2008. The growers in Kenya had to bear additional costs to avoid further environmental deterioration, resulting in a decline in the competitiveness of the Kenyan cut flower industry. Moreover, the exemption of EU tariffs on the exports of flowers from Kenya expired in January 2008, whereas Ethiopia is still exempt from the tariffs. Besides, after the presidential election in December 2007, Kenya experienced political violence in urban centers and some rural areas, including Naivasha, where many of the flower farms are located. Experts believe that the violence has provided or will provide a reason for some flower farms to shift their production sites to Ethiopia.

\section{(b) Demand fluctuations}

The cut flowers are sold in the international market, which can be described as highly demand-driven. The major international markets are the U.S., Europe, the Middle East, and Japan, where only high-quality flowers are traded, and consumers are willing to pay premium prices for them, and there is virtually no domestic market for these flowers in Ethiopia. Furthermore, it is reported that in addition to regular demand seasonality, the 
volume of transactions fluctuates throughout the year with the highest season during Christmas and Valentine’s Day and the lowest season in mid-August (Global Development Solutions, 2006). Thus, the flower farms have to be prepared to respond flexibly to the market demand by constantly monitoring the market trends, and marketing strategies, such as the diversification of markets or the shift to direct sales to retailers, might play an important role in retaining the profitability of each farm.

(c) Capital and labor intensive technology

Observing the production practice, the cut flower industry can be said both capital-using and labor-using. Due to the high sensitivity and vulnerability to climatic conditions such as temperature, sun-shines, wind, and rain, flowers are grown under centrally-controlled greenhouses equipped with air-conditioning units and refrigerated storehouses. Transporting from farm to airport also requires refrigerated trucks. Thus, the initial investment cost in this sector is very high. In addition, as flowers are delicate and vulnerable when harvesting, packaging, and transporting, careful manual labor is essential. It is said that efficient flower production requires at least 20 to 30 workers per hectare in Africa (Whitaker and Kolavalli, 2006). These production workers perform relatively simple tasks such as planting, harvesting, trimming, and packaging, which are closely monitored by supervisors. In an informal interview, one general manager explained that it usually takes less than two months for a novice to learn the tasks in most sections. Further, as there is virtually no domestic market for cut flowers in Ethiopia, all the flowers cultivated need to have export access. These features together make the large-scale 
plantation-oriented production system dominant in this industry (Binswanger and Rosenzweig 1986; Jaffee and Morton, 1995; Hayami 2002). In this kind of environment, because of the simple tasks assigned for the workers and close supervision on their work, the hidden action problem argued by the peer-pressure hypothesis is likely to be unimportant as previously mentioned.

(d) Clusters of cut flower farms

As the flowers are air-freighted, most of the flower farms are located near the capital, and in some areas clusters of these farms can be found. ${ }^{3} \quad$ In our informal interviews we learned that these farms establish an industry association, which, for instance, jointly invite technical consultants from the Netherlands, Israel, and India, and coordinate the transportation of the flowers. In all likelihood, they also share market information and orders from large clients so that they can best respond to demand fluctuations and smooth their production throughout the year. In other villages only a few farms, if any, operate, and cooperation with fellow farms is limited.

\section{DATA AND DESCRIPTIVE ANALYSES}

(a) Data

The primary survey data used in this paper come from 64 cut flower farms in Ethiopia collected by the Ethiopian Development Research Institute collaborating with National Graduate Institute for Policy Studies (GRIPS), Japan. The survey was conducted from the end of 2007 to early 2008. As aforementioned, the data include all the registered cut 
flower farms in Ethiopia, and because there is virtually no domestic market for this industry, all the cut flower farms are necessarily registered enterprises. According to the oral information of the interviewees, there have been no bankruptcies in the past so this survey can be considered as a census survey of the cut flower industry in Ethiopia. We also conducted interviews with randomly selected workers from these 64 cut flower farms. At each cut flower farm, five workers, three female and two male workers, were randomly selected from a list of full-time workers. ${ }^{4}$ In total, we interviewed 320 workers: 188 female workers and 132 male workers.

\section{(b) Descriptive Analyses}

Almost all the workers in the sample are production workers, engaged in simple tasks. To facilitate our understanding of the evolution of the employment channels, we divide our 320 sample workers into three groups by the type of information network connected to the farm: (1) locals born in the same village where the farm is located; (2) friends and relatives invited by the employees, (3) outsiders, who have no such social connections with the farm or its employees. The locals would immediately notice employment opportunities at the farm as its presence is too large to ignore in the neighborhood. As the employees find their working conditions favorable and some positions still vacant, they invite their relatives and friends residing outside the village to work for the farms. Employment opportunities at a farm can also be widely known to outsiders through advertisements, which will be increasingly more effective as the cut flower industry and its labor market as a whole grow. 
Table 2 presents the timing of employment by each group of sample workers. From the share of each group over the years, we can see that the dominant employment channel gradually shifts from the locals to the relatives and the friends of the employees. We also observe an indication of the increasing importance of the workers from outside these social networks. More precisely, 60 percent of the workers hired in 2004 or before, when Ethiopia's cut flower industry just started revealing its presence in the international market, consisted of locals whereas the share of locals among new employees declined over time to 38 percent in 2007. New employees introduced by their friends and relatives working at the farm initially accounted for 33 percent of all new employees, while their share overall increased with slight fluctuation to around 40 to 50 percent. The share of the outsiders among the new employees was eight percent in 2004 or before, but it steadily increased over time and reached as high as 15 percent in 2007.

Let us now examine the characteristics of these workers and of the farms (Table 3). The most striking characteristic is the statistically significant difference in the educational level across the groups; the locals have seven years of schooling on average, the relatives and friends of the employees received slightly more formal education, and the outsiders have nine years of schooling, which partially supports Hypothesis 1. Combined with the findings from Table 2, we can see that the cut flower industry created employment opportunities primarily for low educated people, who are more likely to suffer poverty, and that its development also started attracting workers with higher education, which is in line with Marshall's argument. ${ }^{5}$ Moreover, the workers invited by their relatives and friends live farther away from the farms than the locals, while eight of the 38 outsiders moved into 
the same villages as the farms, which may be related to the fact that the outsiders are more likely to work permanently, as discussed below. Among other characteristics, almost half of the outsiders are male workers, compared to around 40 percent in the other groups, which may at least partly account for their educational difference. The average new worker is in the early twenties, previously worked at 1.2 farms, and has about six months of working experience in the industry, despite the youthfulness of this industry. This indicates that labor turnover is not negligible in this industry, and knowledge diffusion and skill transformation may be enhanced in consequence (Sonobe and Otsuka, 2006).

The outsiders received substantially higher initial wage rates than the workers in the other two groups, which may partly reflect the difference in educational level. This is consistent with Hypothesis 1. However, the wage rate of the locals and the relative-friend group rapidly increased over a short time, and the current wage rate has almost reached the same level as that of the outsiders at around 290 birr per month, which is substantially higher than the average wage rate in the agricultural sector of 200 birr per month. According to the information-cost hypothesis a possible explanation behind these observations is that workers in the local and relative-friend groups have relatively low productivity, part of which may not be observable to econometricians but to employers, and the workers relied on the informal networks in job application as they were less likely able to find jobs otherwise. However, considering that the major tasks required for the production workers are quite simple, the wage curve with respect to labor productivity is likely to be nonlinear and soon hits the ceiling. The workers with social ties are able to catch up with their fellow outsiders after a few months at the farm and climb up the wage 
curve. Thus the outsiders who were recruited formally lose their wage premium in the current wages.

The percentage of workers paid monthly, in contrast to daily or weekly bases, was initially much lower among the relative-friend group at around 10 percent compared with more than 20 percent among the locals and the outsiders. This percentage soon increased in all three groups, and particularly among the relative-friend group it reached over 40 percent, which is currently even higher than the 34 percent for the outsiders.

We have already discussed the high demand fluctuations in this industry. The farms employ some workers temporarily or seasonally to cope with this problem, whereas permanent employees work for the farm throughout a year. The percentage of permanent workers is substantially higher among the locals and the outsiders than among the relative-friend group, who come from a distance and help only in busy seasons. We can also see from Table 3 that around forty percent of the workers sign a formal contract, which we consider as an indication of the importance of such workers to the farms.

We now turn our attention to the characteristics of the cut flower farms. Reflecting the youthfulness of this industry, the years of operation of the farms when hiring these sample workers is less than one year. Comparing the operation years across the worker groups, we find that the farms initially hire locals (or the farms have the shortest years of operation when hiring locals), and they employ the relative-friend workers and the outsiders after operating for a certain period, which is in line with the finding from Table 2. The average employment size of a cut flower farm is around 300 workers, and we can see from Table 3 that locals are hired when farms are young and small. When farms become 
large, then they also tend to rely on the friends and relative group or outside recruitment. The average years of operation as of 2007 is 2.4 years for domestic ownership farms, 1.8 years for foreign ownership farms, and 2.1 years for joint venture farms. Presumably and partly reflecting this difference in operation years, foreign ownership farms hired more of the locals (accounting for 45 percent of their employees) than domestic ownership farms (29 percent) and joint venture farms (26 percent).

More importantly, 53 percent of the employees at the farms located in the industrial clusters were outsiders, who have higher human capital (the last row in Table 3), whereas only 12 percent of the workers in the entire cut flower industry were outsiders (the last row in Table 2). The average years of schooling within the cluster is 7.86 years while that of outside the cluster is 7.11 years and the difference is statistically significant at 6 percent. This suggests that the labor market within the clusters is more developed and attracts more workers with higher human capital than outside the clusters, and thus hiring high-quality workers through open recruitment can be a major option in employment, whereas the labor markets may not be as well developed outside the cluster, which is in line with Hypothesis 2. By contrast, only 22 percent of the employees inside the clusters were the relatives and friends of the employees (the last row in Table 3), whereas they account for as much as 44 percent of the workers in the industry as a whole (the last row in Table 2).

\section{ESTIMATION STRATEGY}

We will estimate the initial monthly wage regression model. The dependent variable is the natural $\log$ of the real initial monthly wage at hiring, $t=0$, of a worker $i$ at a farm $k$ : 


$$
\ln \left(w_{i k 0}\right)=\beta_{0}^{L} D_{L}+\beta_{0}^{R F} D_{R F}+x_{i k 0} \beta_{0}^{x}+z_{k 0} \beta_{0}^{z}+\varepsilon_{i k 0}
$$

where $D_{L}$ is the dummy variable indicating whether the employee acquired the job through the local network $\left(D_{L}=1\right)$ or not $\left(D_{L}=0\right)$, and, similarly, $D_{R F}$ is the dummy variable indicating whether the employee acquired the job through invitation from their relatives and friends working at the farm $\left(D_{R F}=1\right)$ or not $\left(D_{R F}=0\right)$. We also control for workers characteristics at hiring $\left(x_{i k 0}\right)$, which includes the dummy variables of employment year as well as human capital characteristics (the worker's gender, age, years of schooling, years of experience in the cut flower industry, and the number of farms that s/he has worked at) and the distance between home and the farm, and the farm's characteristics at hiring $\left(z_{i k 0}\right)$, which include years of operation, employment size, ownership type, and whether the farm was located within or outside the clusters. Note that as the workers were hired at different points in time, we use individual and cut flower farm characteristics which were specific to the time of hiring, and also the dummy variables of the employment year to control for the effects of the changing importance of local and personal networks and the emergence of the labor market. We will use the OLS and the farm-level fixed-effects method to estimate this regression function (1). Hypothesis 1 predicts that the estimated coefficients on the local network dummy $D_{L}$ and on the personal network dummy $D_{R F}$ will have negative signs. Moreover, if Hypothesis 2 is true, the estimated coefficient on the cluster dummy will be negative. We will next regress the current monthly wage on the same set of explanatory variables as in regression function (1), and particularly examine which variables persistently affect a worker's earnings and which do not.

We will also examine the associations of monthly payment schemes with the 
worker's and the farm's characteristics and their changes over time, as well as the determinants of permanent position and formal contracts. To facilitate our understanding of the evolution of the labor market conditions in the cut flower industry as a whole, we will regress these dependent variables on the same set of explanatory variables as in regression function (1).

\section{ESTIMATION RESULTS}

(a) Initial and current monthly wage

The first two columns of Table 4 present the initial monthly wage model, estimated by the OLS and farm-FE method, respectively. The outside workers received significantly higher initial monthly wages of 20 percent more than the workers recruited through the local and the personal relationships, which supports Hypothesis $1 .^{6}$ Notice that we already control for the variables indicating human capital characteristics, but the dummy variables for the locals and the relative-friend groups still have highly significant negative coefficients. This result suggests a possibility that the employers can see some aspects of worker's productivity, such as deftness, that are not fully reflected in our dataset. Despite this limitation, the estimated coefficients on our human capital variables still indicate that older (or, "more experienced" in a broad sense), male, highly educated workers tend to receive higher initial monthly wages. Being male increases the initial wage by eight percent, ${ }^{7}$ while an additional year of age adds less than one percent, and an additional year of schooling adds around one percent. As for the farm's characteristics, younger and foreign-owned farms tend to pay higher monthly wages. More importantly, the farms 
located outside the industrial clusters pay significantly higher monthly wages, which supports Hypothesis 2. The increasingly positive coefficients on the dummy variables indicating the employment year of the worker may suggest that the productivity of job seekers attracted to this growing industry had been increasing, partly due to the development of its labor market.

The estimated model of current monthly wage is presented in the third and fourth columns of Table 4. Most importantly, the statistical significance of the effects of the local and the relative-friend dummy variables disappeared. Consistent with the descriptive analysis in Table 3, this result suggests that the monthly wage of the workers among the locals and the relative-friend groups increased at higher rates than that of the outside workers, probably because these workers also increased their productivity through learning. As aforementioned, because the tasks assigned at flower farms are simple, the wage curve over labor productivity is likely to reach the maximum level quickly. Thus, the workers in the local and relative-friend groups, who were at the lower productivity level than the outsiders, can learn the work quickly and catch up with the formally-recruited workers in a short time. This fact that even workers initially equipped with relatively low human capital become capable of handling more difficult tasks over the years indicates the potential role of this industry in alleviating poverty for poor Ethiopian farmers.

The estimated effects of being male and receiving higher education are stronger on the current monthly wage than on the initial monthly wage, which suggests that educated male workers were probably offered more sophisticated tasks over the years. The number of flower farms that a worker has worked at also has a significantly positive effect on the 
monthly wage rate, according to the OLS estimate. More importantly, the farms located outside the industrial clusters still pay significantly higher monthly wages than the farms within the clusters, which supports Hypothesis 2, and this "premium” has increased from eight percent at hiring to more than ten percent currently. We also notice that younger farms still tend to pay higher monthly wages. The negative coefficient on the employment year dummy for the newest workers suggests that these less experienced workers were still learning.

(b) Monthly payment scheme

Table 5 presents the estimated models of the workers paid monthly, as opposed to the daily/weekly payment scheme, at the beginning of employment and currently, separately. Whether the farms are paying on a monthly basis or not shows the commitment of the farm and thus is indicative of how important the worker is to the farm. We can see that the workers in the relative-friend group were less likely to be paid monthly at the beginning of employment, compared especially to the outsiders, which is in line with Hypothesis 1 . We saw in Table 3 that the percentage of workers under the monthly payment scheme increased substantially over the years among all the three groups, and the increase was the largest in the relative-friend group. In fact, the third and fourth columns in Table 5 indicate that the significant difference in the percentage of monthly paid workers across the worker groups disappeared over the years, suggesting that the farms tend to provide more secured positions to their workers regardless of their employment channel.

Male workers were initially more likely to be paid monthly by six percentage points, 
although the gender difference disappeared after some time. By contrast, educated workers were more likely to be paid on a monthly basis from the beginning to the present; for instance, five additional years of education increase the probability of being paid monthly by 10 percentage points. Furthermore, the years of experience working in this industry reveals its increasingly positive effect on the monthly payment scheme. The number of farms that a worker has worked at has negative coefficients, increasing in absolute terms, which indicates that the workers who frequently change their employers receive wage on a daily or weekly basis.

The farms located outside the industrial clusters tend to pay their employees on a monthly basis probably to attract those workers, which is consistent with Hypothesis 2 . The increasing absolute value of the coefficient on the cluster dummy indicates that the farms outside the clusters made an increasing effort to obtain their skilled and experienced employees. We also find that the foreign ownership farms tend to offer monthly payment schemes to new employees more often than the domestic ownership farms, but this difference disappeared over the careers of the workers.

(c) Permanent workers and formal contracts

The first two columns in Table 6 present the estimated model on the determinants of being a permanent worker. The status of a permanent worker suggests the importance of the worker to the farm as well as how well the farm plans their labor inputs to meet their production schedule. For example, if the farms can predict the market demand well and develop their production plan accordingly, it is more efficient for the farms to rely on 
permanent workers than temporary workers as adjusting the labor inputs using the temporary workers is costly. The outsiders are more likely to be offered work throughout the year probably due to their higher productivity, which is consistent with Hypothesis 1, whereas the workers invited by the employees at the farm from a distance tend to be seasonal workers. This result seems consistent with the result that the workers invited by their relatives and friends employed at the farm tend to be paid daily or weekly, rather than monthly (Table 5).

We find, among worker's human capital characteristics, that the educated workers tend to work throughout the year. More precisely, an additional year of schooling raises the probability of being hired as a permanent worker by 1.5 percentage points. As for the farm's characteristics, younger and joint-venture farms are more likely to hire workers permanently rather than temporarily. More importantly, the farms located within the industrial clusters may be better at coping with demand fluctuations or seasonality by sharing market information and orders with neighboring farms. In fact, the farms within the industrial clusters tend to depend more on permanent workers, and use fewer temporary/seasonal workers.

The last two columns of Table 6 present the estimated model of the workers signing formal contracts with the farms. A formal contract shows the commitment of the farm to the worker and thus indicates the importance of the worker to the farm. The outsiders tend to sign formal contracts with the farm more often than with the locals and especially more than with the workers introduced by the employees at the farms, probably due to their high productivity, which is in line with Hypothesis 1 . We can also see that the farms 
attempt to secure educated workers and those coming from a distance by signing formal contracts with them.

The farms located outside the industrial clusters tend to secure their workers by signing formal contracts, which is further supportive evidence for Hypothesis 2. We can also see that joint venture farms tend to sign formal contracts with their workers. The results on the farm's years of operation and employment size at hiring and on the dummy variables indicating the employment year are different between the OLS model and the farm-level FE model, which is most likely due to the correlation between the farm fixed effects and these variables.

\section{CONCLUSION}

Using the survey data of all the 64 cut flower farms in Ethiopia as of 2007 and the 320 workers randomly sampled from these farms, we examined the evolution of the employment channels and the early development of the labor market for this young industry. We found that the local and the personal networks initially played an important role in disseminating information on employment opportunities, and those recruited informally using these social ties were paid less than the formally-recruited workers at hiring. However, even these workers quickly increased their productivity and the effect of social ties on wages disappeared over time. Furthermore, the results of our statistical analyses consistently suggest that the development of the labor market took place particularly within the industrial clusters, which supports the famous argument of Marshall on the advantage of such clusters. 
The cut flower industry has created employment opportunities for 21,786 workers in Ethiopia as of 2007. One bright feature of this industry is that most of these employees were initially poor farmers equipped with only low human capital and without many other employment opportunities, but they could quickly learn the tasks at the cut flower farms and their wages soon exceeded that of the average agricultural workers by more than 20 percent. A simple back-of-the-envelope calculation suggests that such favorable employment opportunities were increasing rapidly; simply applying the growth rate in the industry's export value from USD 69 million in 2007 to USD 104 million in 2008 to the employment would suggest that the cut flower industry employed around 33,000 workers in 2008. Moreover, thanks to the development of the labor market, the growth in the cut flower industry will have a significant impact on the alleviation of poverty.

Our analysis has revealed the benefits of labor markets, which started successfully developing particularly within industrial clusters. In forming an industrial policy, the government should take into account these benefits of labor markets and the role that an industrial cluster can play in the development of markets. Furthermore, the miraculous growth in the cut flower industry in Ethiopia may not have been realized without the initial strong support of the government. As aforementioned, however, the market of this export-oriented industry is highly demand driven, which implies that the industry as a whole is vulnerable to a large demand shock in the international market, and the government should be prepared for such a risk. Our results also confirm the importance of education in job acquisition and earnings, which should further encourage the current effort of the government to improve its educational system. 
1 In the literature, an industrial cluster is usually defined as the geographical concentration or localization of enterprises producing closely related goods in a small area. In our case, 14 cut flower farms out of the 64 were located in one village, and 13 were in another, whereas the other farms were scattered across different villages. Thus, we refer these two villages as the industrial clusters throughout this paper.

2 Examples include their roles in consumption smoothing (Fafchamps and Lund, 2003), agricultural marketing (Fafchamps and Minten, 2002), capital mobilization for factory establishment (Banerjee and Muhshi, 2000; Fafchamps, 2000), technology diffusion (Conley and Udry, 2010), and the prevention of tenant farmers' shirking (de Janvry, Sadoulet, and Fukui, 1997).

3 More precisely, Welmera woreda (meaning village) had 14 out of the 64 farms, while Holeta woreda had 13 farms in 2007.

4 Each observation is given an equal weight in the following analysis as well as in the sample selection, irrespective of the size or male-female ratio of employment at each farm. To check if our estimation results are subject to the sample selection, we have estimated the same regression models in the paper by using the weighted least square estimation models. The results are similar to what we find in the paper, and are available upon request.

${ }^{5}$ For comparison, the years of schooling of the general managers was 15.8 years in the cut flower industry as of 2007, indicating that they were exceptionally highly educated for the country. In general, the adult literacy rate - the percentage of persons aged 15 and over who can read and write - is estimated to be 36 percent during the period between 2003 and 2008 (Unicef, accessed on March 9, 2010, at http://www.unicef.org/infobycountry/ethiopia_statistics.html). The expected years of schooling that a child will receive is estimated to be 8 years as of 2008 (See CIA's "school life expectancy" at https://www.cia.gov/library/publications/the-world-factbook/geos/et.html) accessed on March 10, 2010.) 
${ }^{6}$ We also attempted to investigate the development of labor market and the changing nature of the labor pool by interacting the informal network variables with dummy variables indicating whether the worker was hired before 2005 or after 2006. The estimation result is that the workers who replied on the informal networks in early periods received significantly lower wages as the outsiders, whereas such significant difference in the initial wage disappeared in the later period. This result indicates increasing productivity of workers employed through the informal networks.

${ }^{7}$ As an attempt to further analyze the male-female differences, we have conducted all regression models separately for men and women. The results from the men's and women's models are similar overall. We suspect that we do not have enough observations to identify systematic differences in the models between men and women. 


\section{References}

Antoninis, Manos. (2006). "The wage effects from the use of personal contacts as hiring channels,” Journal of Economic Behavior and Organization, 59: 133-146.

Banerjee, A., \& Munshi, K. (2000). "Network, Migration and Investment: Insiders and Outsiders in Tirupur's Production Cluster,” working paper no. 00-08, Department of Economics, Massachusetts Institute of Technology.

Banerjee, B. (1984). "Information Flow, Expectations and Job Search: Rural-to-Urban Migration Process in India,” Journal of Development Economics, 15: 292-311.

Ben-Porath, Y., (1980). “The F-connection: families, friends and firms and the organization of exchange,” Population and Development Review 6, 1-30.

Binswanger, Hans P., and Mark R. Rosenzwerig. 1986. "Behavioural and Material Determinants of Production Relations in Agriculture.” Journal of Development Studies 22, no. 3: 503-540.

Carrington, W.J., Detragiache, E., Vishwanath, T., (1996). "Migration with endogenous moving costs,” American Economic Review 86, 909-930.

Collier, P., and Garg, A., (1999). "On kin groups and wages in the Ghanaian labour market,” Oxford Bulletin of Economics and Statistics 61, 133-151.

Conley, T., \& Udry, C. (2010). “Learning about a New Technology: Pineapple in Ghana,” American Economic Review 100:1, 35-69.

de Janvry, A., Sadoulet, E., \& Fukui, S. (1997). "The Meaning of Kinship in Share-Cropping Contracts,” American Journal of Agricultural Economics 79:394-406. Embassy of Japan in Ethiopia. (2008). A Series of Studies on Industries in Ethiopia. 
[Online: <http://www.et.emb-japan.go.jp/>.]

Fafchamps, M. (2000). "Ethnicity and Credit in African Manufacturing," Journal of Development Economics 61:205-35.

Fafchamps, M., \& Lund, S. (2003). “Risk Sharing Networks in Rural Philippines,” Journal of Development Economics, 71:261-87.

Fafchamps, M., \& Minten, B. (2002). "Returns to Social Network Capital among Traders,” Oxford Economic Paper, 54: 173-206.

Frijters, P., (1999). "Hiring on the basis of expected productivity in a South African clothing firm,” Oxford Economic Papers 51, 345-354.

Gebreeyesus, M. \& Iizuka, M. (2010) "Discovery of the Flower Industry in Ethiopia: Experimentation and Coordination.” United Nations University MERIT Working Paper Series \#2010-025.

Global Development Solutions. (2006). Integrated value chain analysis for the floriculture (rose) sector in Ethiopia. [prepared for the Government of Ethiopia and the World Bank.]

Granovetter, M. (1974). Getting a Job: A Study of Contacts and Careers. Cambridge, MA: Harvard University Press.

Hayami, Yujiro. 2002. "Family Farms and Plantations in Tropical Development.” Asian Development Review 19, no. 2: 67-89.

Holzer, H. J. (1988). "Search Method Use by Unemployed Youth,” Journal of Labor Economics, 6 (1): 1-20.

Holzer, H.J., (1996). What Employers Want: Job Prospects for Less-educated Workers, 
Russell Sage Foundation, New York.

Jaffee, Steven, and John Morton. 1995. Marketing Africa's High-Value Foods. Dubuque, IA: Kendall/Hunt Publishing Company

Kajisa, K. (2007). "Personal Networks and Nonagricultural Employment: The Case of a Farming Village in the Philippines,” Economic Development and Cultural Change, 55 (4): 669-707.

Kugler, A.D., 2003. Employee referrals and efficiency wages. Labour Economics 10, $531-556$.

Luke, N., \& Munshi, K. (2006). "New Roles for Marriage in Urban Africa: Kinship Networks and the Labor Market in Kenya,” Review of Economics and Statistics, 88 (2): $264-82$.

Marshall, A. (1920). Principles of Economics, London: Palgrave Macmillan.

Milgrom, P., \& Roverts, J. (1992). Economics, Organization, and Management. Upper Saddle River, NJ: Princeton Hall.

Montgomery, J. D. (1991). "Social Networks and Labor Market Outcomes: Toward an Economic Analysis.” American Economic Review, 81 (5):1408-18.

Mortensen, D. T. ,\& Vishwanath, T. (1994). “Personal Contacts and Earnings.” Labour Economics 1:187-201.

Munshi, K. (2003). “Networks in the Modern Economy: Mexican Migrants in the U.S. Labor Market,” Quarterly Journal of Economics, 118 (2): 549-97.

Otsuka, K., Estudillo, J., \& Sawada, Y. (2009). Rural Poverty and Income Dynamics in Asia and Africa, New York: Routledge. 
Pissarides, Christopher A. (2000). Equilibrium Unemployment Theory, Cambridge, MIT Press.

Pistaferri, L., (1999). "Informal networks in the Italian labor market,” Giornale degli Economisti e Annali di Economia 58, 355-375.

Putnam, R. D. (2000). Bowling Alone. New York: Simon \& Schuster.

Saloner, G. (1985). “Old Boy Networks as Screening Mechanisms.” Journal of Labor Economics 3 (3): 255-67.

Salop, Steven C. (1979), “A Model of the Natural Rate of Unemployment,” American Economic Review, 69: 17-25.

Schlicht, Ekkehart (1978), “Labour Turnover, Wage Structure, and Natural Unemployment,” Journal of Institutional and Theoretical Economics (Zeitschrift für die gesamte Staatswissenschaft), 134(2): 337-364.

Simon, C. J., \& Warner, J. T. (1992). "Matchmaker, Matchmaker: The Effect of Old Boy Networks on Job Match Quality, Earnings, and Tenure,” Journal of Labor Economics, 10 (3): 306-30.

Sonobe, T., \& Otsuka, K. (2006). Cluster-Based Industrial Development: An East Asia Model, Palgrave Macmillan, New York.

--- and --- (2010). Cluster-Based Industrial Development: A Comparative Study of Asia and Africa, Palgrave Macmillan, New York.

Stigler, George J. (1961). “The Economics of Information,” Journal of Political Economy, 69 (5), pp. 213-25.

--- (1962). “Information in the Labor Market,” Journal of Political Economy, 70 (5), pp. 
94-105.

Stiglitz, Joseph. (1987), “Causes and consequences of dependence of quantity upon price,” Journal of Economic Literature, 25(1): 1-48.

Whitaker, M., \& Kolavalli, S. (2006). "Floriculture in Kenya,” in Vandana Chandra ed., Technology, Adoption, and Exports: How Some Developing Countries Got It Right. Washington: the World Bank, 2006.

Yamauchi, F., \& Tanabe, S. (2008). “Nonmarket Networks among Migrants: Evidence from Metropolitan Bangkok, Thailand,” Journal of Population Economics, 21: 649-664. 
Table 1. Export of Ethiopia and Cut Flower Export of the Top African Exporters (Million US\$)

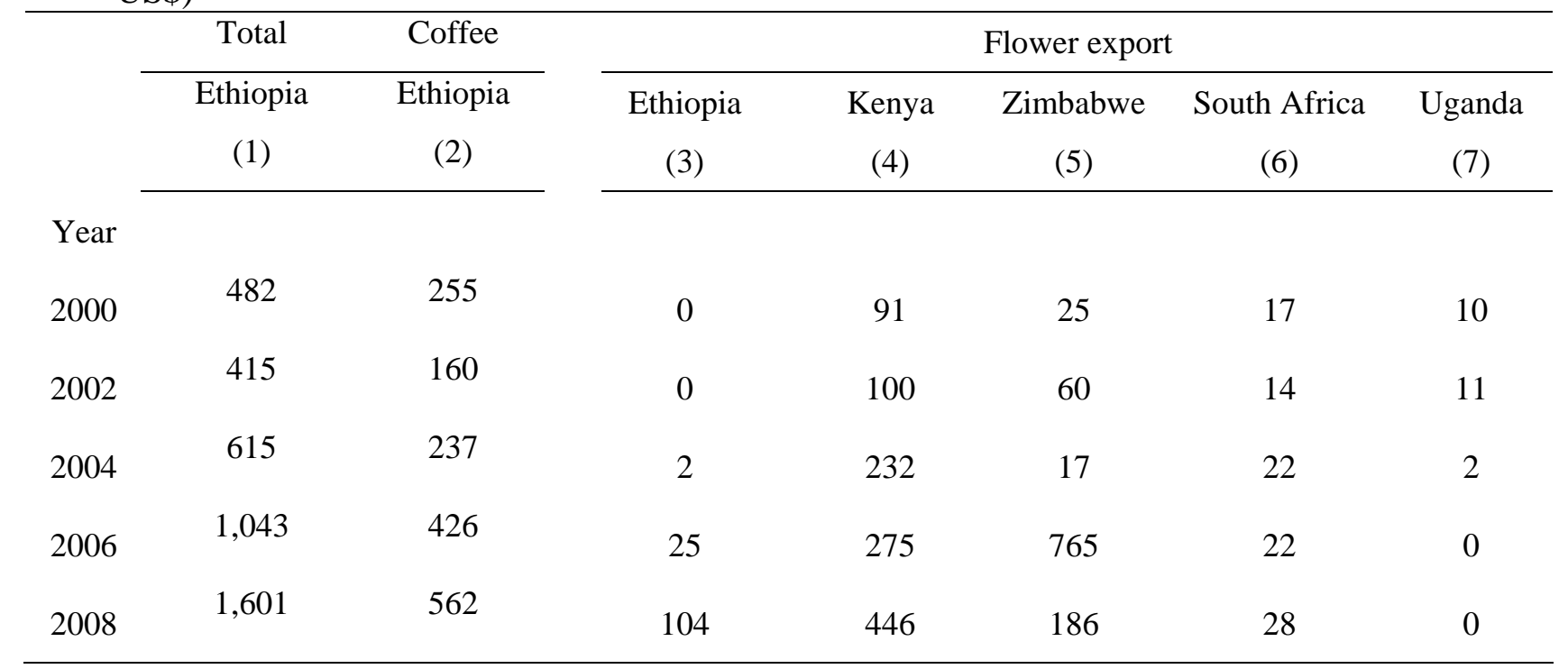

Source: UN COMTRADE

(http://comtrade.un.org/db/default.aspx, accessed on March 9, 2010) 
Table 2. Timing of Employment of the Sample Workers by Type of Worker

\begin{tabular}{lcccc}
\hline & Locals & $\begin{array}{c}\text { Relatives and friends of the } \\
\text { employees }\end{array}$ & Outsiders & Total \\
\cline { 2 - 5 } & $(1)$ & $(2)$ & $(3)$ & $(1)+(2)+(3)$ \\
\hline Year & & & & \\
2004 or before & 27 & 15 & 4 & 46 \\
& $(59)$ & $(33)$ & $(8)$ & $(100)$ \\
2005 & 28 & 35 & 7 & 70 \\
& $(40)$ & $(50)$ & $(10)$ & $(100)$ \\
2006 & 50 & 42 & 13 & 109 \\
& $(46)$ & $(42)$ & 14 & $(100)$ \\
2007 & 36 & 45 & $(15)$ & 95 \\
& $(38)$ & $(47)$ & 38 & $(100)$ \\
\hline No. of obs. & 141 & 141 & $(12)$ & $(100)$ \\
& $(44)$ & $(44)$ & & \\
\hline
\end{tabular}

Notes: (1) The workers in the "locals" group were born in the village where the farm is located. The workers in the second group were invited by their relatives and friends working at the farm. The workers in the "outsiders" group have neither local nor personal relationships with the farm or its employees.

(2) The numbers in parentheses are the \% of workers belonging to each category in each year. 
Table 3. Worker and Farm Characteristics by Type of Worker

\begin{tabular}{|c|c|c|c|c|c|c|}
\hline & \multirow{2}{*}{\multicolumn{2}{|c|}{$\begin{array}{c}\text { Relatives } \\
\text { and } \\
\text { friends } \\
(2) \\
\end{array}$}} & \multirow{2}{*}{$\begin{array}{c}\text { Outsiders } \\
\text { (3) } \\
\end{array}$} & \multicolumn{3}{|c|}{$p$-value for mean test ${ }^{(a)}$} \\
\hline & & & & (1) vs (2) & (1) vs (3) & $(2)$ vs (3) \\
\hline \multicolumn{7}{|l|}{ Worker Characteristics at hiring } \\
\hline Female (\%) & 61.7 & 57.4 & 52.6 & 0.468 & 0.314 & 0.597 \\
\hline Age & 23.0 & 23.1 & 21.9 & 0.870 & 0.337 & 0.335 \\
\hline Years of schooling & 6.97 & 7.35 & 8.92 & 0.436 & $0.015^{* *}$ & $0.040^{* *}$ \\
\hline Years of experience in the industry & 0.57 & 0.37 & 0.61 & 0.175 & 0.870 & 0.284 \\
\hline $\begin{array}{l}\text { Number of flower farms that s/he has } \\
\text { worked at }\end{array}$ & 1.25 & 1.17 & 1.29 & 0.158 & 0.636 & 0.170 \\
\hline Distance from home to the farm (km) & 3.49 & 4.97 & 3.88 & $0.002 * * *$ & 0.506 & $0.006^{* * *}$ \\
\hline \multicolumn{7}{|l|}{ Wage rate (Birr ${ }^{(b)} /$ month) } \\
\hline At hiring ${ }^{(c)}$ & 173.2 & 182.9 & 276.6 & 0.206 & $0.002 * * *$ & $0.006^{* * *}$ \\
\hline Current & 283.2 & 286.9 & 297.2 & 0.776 & 0.537 & 0.639 \\
\hline \multicolumn{7}{|l|}{ Monthly payment scheme $^{(\mathrm{d})}(\%)$} \\
\hline At hiring & 22.0 & 10.6 & 21.1 & 0.009 & 0.902 & $0.089 *$ \\
\hline Current & 43.3 & 43.3 & 34.2 & 1.000 & 0.317 & 0.317 \\
\hline Permanent workers ${ }^{(\mathrm{e})}(\%)$ & 41.8 & 23.4 & 44.7 & $0.0009 * * *$ & 0.750 & $0.009 * * *$ \\
\hline Formal contract (\%) & 43.3 & 37.6 & 42.1 & 0.333 & 0.899 & 0.614 \\
\hline \multicolumn{7}{|l|}{ Farm Characteristics at hiring } \\
\hline Years of operation & 0.39 & 0.82 & 0.78 & $0.001 * * *$ & $0.010 * * *$ & 0.855 \\
\hline Employment size & 253.3 & 300.2 & 276.5 & $0.012 * *$ & 0.419 & 0.431 \\
\hline \multicolumn{7}{|l|}{ Ownership (\%) } \\
\hline Domestic & 29.0 & 45.3 & 26.3 & $0.004 * * *$ & 0.739 & $0.034^{* *}$ \\
\hline Foreign & 43.9 & 34.0 & 52.6 & $0.088^{*}$ & 0.344 & $0.036 * *$ \\
\hline Joint venture & 26.9 & 20.5 & 21.0 & 0.209 & 0.463 & 0.948 \\
\hline Located in cluster ${ }^{(\mathrm{f})}(\%)$ & 41.8 & 22.0 & 52.6 & $0.0003^{* * *}$ & 0.237 & $0.0002^{* * *}$ \\
\hline
\end{tabular}

Notes: (a) * indicates statistical significance at $10 \%$; ** at $5 \%$; *** at $1 \%$.

(b) 1 Birr $=0.1$ USD as of 2008.

(c) Adjusted for inflation (in 2007 birr) using the CPI (World Economic Outlook 2008, IMF).

(d) The other payment schemes are on a daily or weekly basis.

(e) The other category is temporary or seasonal workers.

(f) Farms located in Welmera and Holeta are in the cluster. 
Table 4. Determinants of Initial and Current Wage Rates

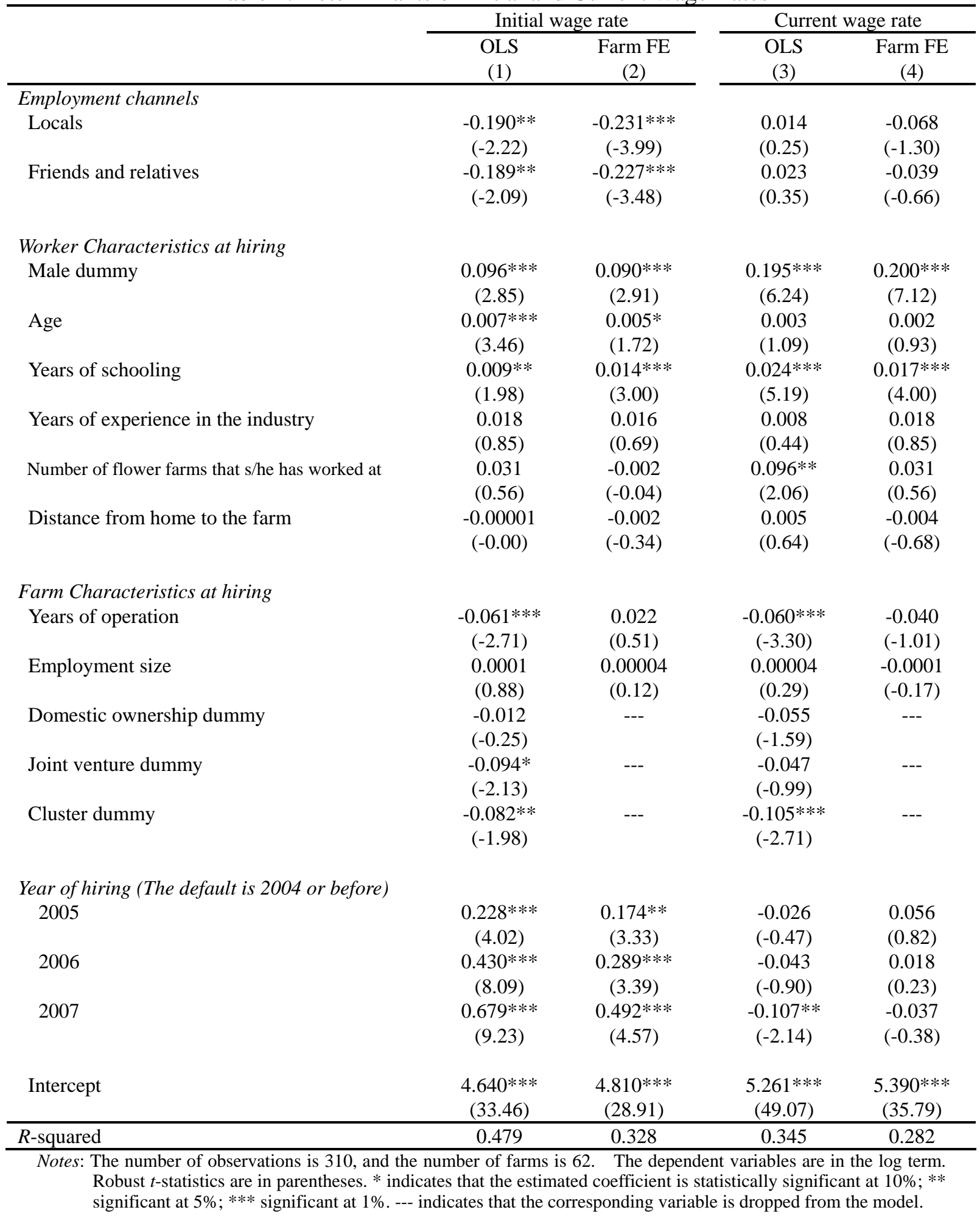


Table 5. Initial and Current Monthly Payment Schemes (LPM)

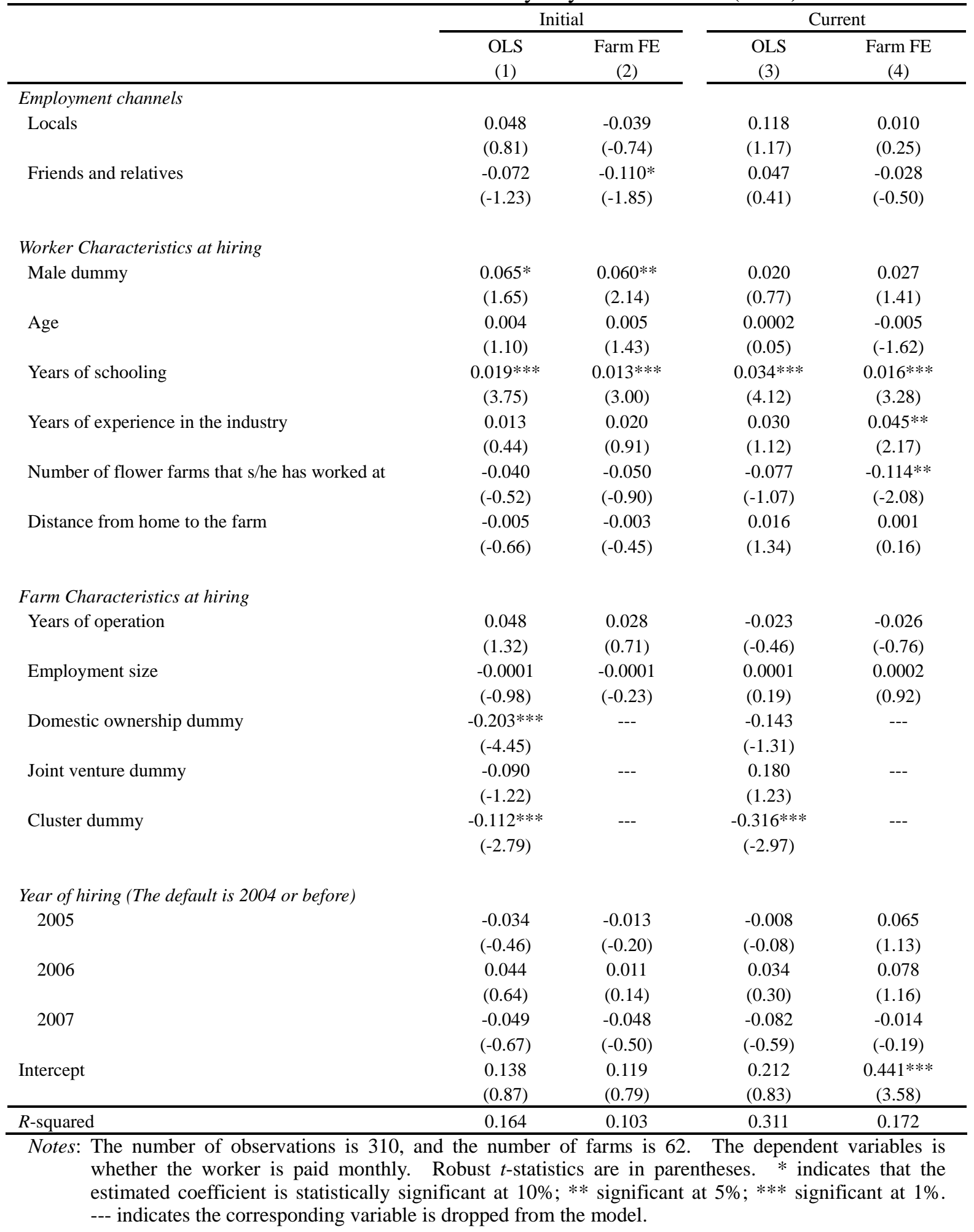


Table 6. Permanent Workers and Formal Contracts (LPM)

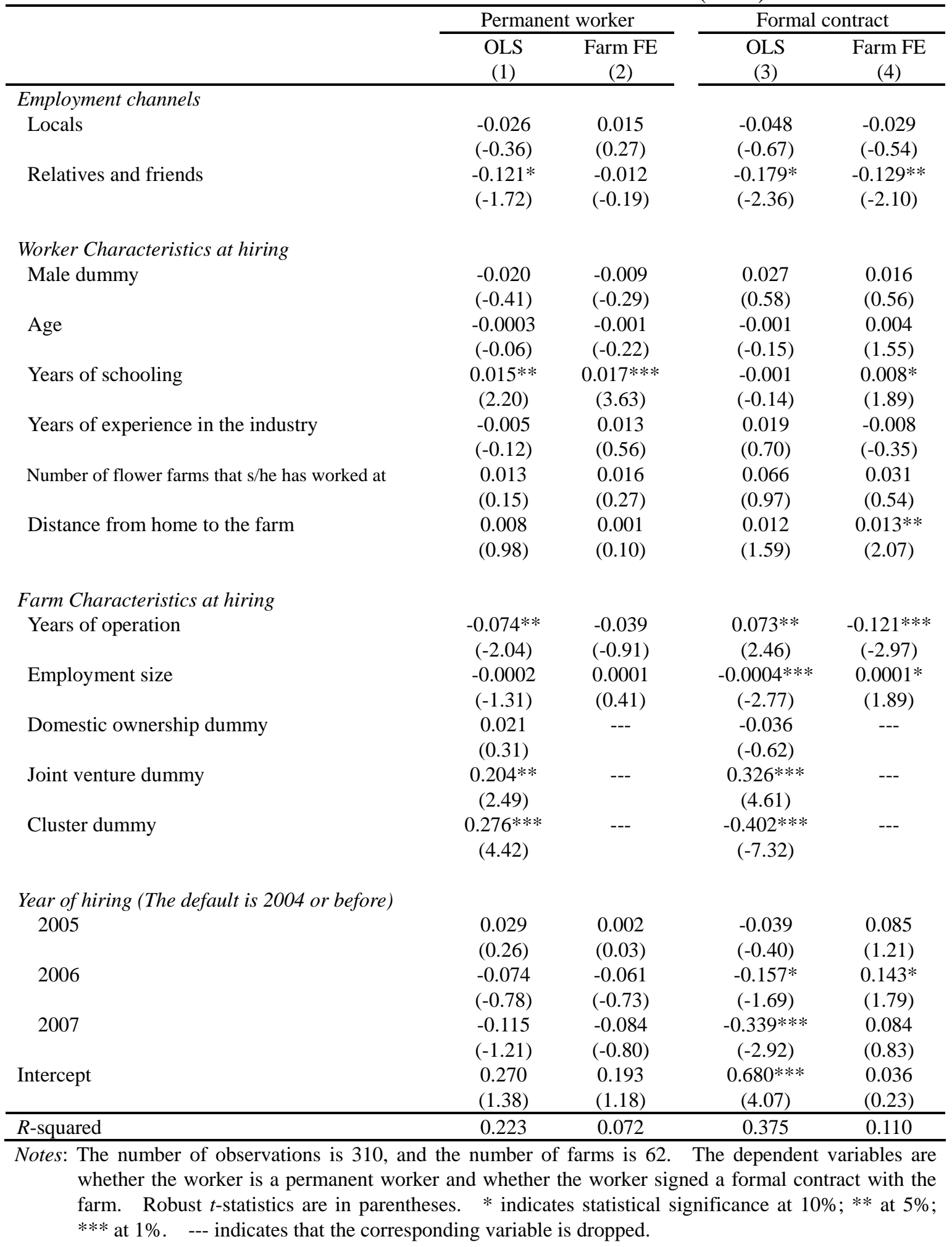

